\title{
Isolation of Bacteria and Physicochemical Analyses of Petroleum-Products Contaminated Soil from NNPC/PPMC Depot, Benin City, Nigeria
}

\section{Akeredolu DO* and Akinnibosun FI \\ Department of Microbiology, University of Benin, Nigeria}

*Corresponding author: Akeredolu DO, Department of Microbiology, University of Benin, Benin City, Nigeria, E-mail: dennisakeredolu@gmail.com

\section{Research Article}

Volume 2 Issue 2

Received Date: April 19, 2017

Published Date: May 02, 2017

DOI: $10.23880 /$ oajmb-16000118

\section{Abstract}

This study was aimed to evaluate the physico-chemical properties and presence of bacteria of from soil samples contaminated with different petroleum products which are petrol (PMS), diesel (AGO), pure kerosene (DPK) and mixed kerosene (DPK) obtained from the tank farm of NNPC/PPMC Depot in Benin City, Nigeria. The mean count for heterotrophic bacterial ranged from $1.83 \times 10^{4} \pm 0.09 \mathrm{cfu} / \mathrm{g}$ soil contaminated with mixed DPK to $5.93 \times 104 \pm 0.02 \mathrm{cfu} / \mathrm{g}$ for soil contaminated with PMS. Nine (9) bacterial isolates were characterized and identified; Bacillus subtilis, Micrococcus varians, Pseudomonas aeruginosa, Klebsiellaaerogenes, Alcaligenes sp., Corynebacterium sp., Bacillus sp., Arthrobacter sp., and Pseudomonas sp.Bacillussp. and Pseudomonassp. were the most occurring bacteria isolates in the four soil samples. From the physico-chemical analysis, the $\mathrm{pH}$ value ranged from 6.50-6.70, electrical conductivity ranged from $14.20 \mathrm{mhos} / \mathrm{cm}-32.50 \mathrm{mhos} / \mathrm{cm}$, moisture content from $10.20 \%-14.50 \%$, carbon from $1.38 \%-2.97 \%$, nitrogen from 2.37\%-8.19\%, 0.396\%-0.950\%, phosphate 1.95\%-5.52\% and total hydrocarbon from $125 \mathrm{mg} / \mathrm{kg}-3,050 \mathrm{mg} / \mathrm{kg}$ These results revealed that the presence of these bacteria under the stated soil condition can enhance bioremediation of petroleum contaminated soil. This study reveals the possible biodegradability of several petroleum products by bacteria which will aid the bioremediation of the contaminated soil.

Keywords: Bacteria; Physicochemical Analyses; Petroleum-Products; Contaminated Soil

\section{Introduction}

Activities associated with petroleum exploration, development and production operations have local detrimental and significant impacts on the atmosphere, soils and sediments, surface and groundwater, marine environment, biological diversity and sustainability at terrestrial ecosystems in the Niger Delta [1]. Discharge of petroleum hydrocarbon and petroleum-derived waste, streams have caused environmental pollution, adverse human health effects, and detrimental impact on regional economy, socio-economy problem and degradation of 


\section{Open Access Journal of Microbiology \& Biotechnology}

host communities in the 9 oil-producing states in the Niger Delta region [1]. Recently, anthropogenic practices such as industrial activities, petroleum and petroleum derivatives (such as gasoline, diesel, and kerosene spills), and incomplete combustion of fossil fuels have caused an accumulation of petroleum hydrocarbons in the environment [2]. In fact, petroleum and derivatives have a major ecological impact on contaminated marine and terrestrial ecosystems [2]. Many important processes influence the destination of hydrocarbons in the environment. Among these are sorption, volatilization, abiotic transformation (chemical or photochemical), and biotransformation [3]. Biodegradation of oil contaminated soils, which exploits the ability of microorganisms to degrade and/or detoxify organic contamination, has been established as one of the efficient, economic, versatile and environmentally sound treatment [4].

The presence of a high enzymatic capacity allows microbial communities to degrade complex hydrocarbons [5]. This capacity to modify or decompose certain pollutants, such as petroleum, summarizes the importance of enzymes in the bioremediation process. Their genetic diversity contributes to the metabolic versatility of microorganisms for the transformation of contaminants into less-toxic final products, which are then integrated into natural biogeochemical cycles [5]. However, appropriate environmental factors such as $\mathrm{pH}$, available nitrogen and phosphorus, Organic matter, moisture and carbon content are essential for the performance of these organisms. The application of nutrients to oil contaminated site to stimulate the growth of naturally occurring hydrocarbon utilizing bacteria for bioremediation purpose, can greatly improve the rate of recovering of environments contaminated with petroleum products. Therefore this study was aimed to Isolation of Bacteria and Physicochemical Analyses of PetroleumProducts Contaminated Soil from NNPC/PPMC Depot, Benin City, Nigeria.

\section{Materials and Methods}

Soil samples contaminated with petroleum products (diesel, petrol, pure and mixed kerosene) were collected from tank draining points from tank farm at NNPC/PPMC Benin deport. Samples were collected at different point from the tank farm into polyethylene bags which were duly labelled and transported to the laboratory. All glassware used were thoroughly washed, air dried and sterilized using an autoclave at $121^{\circ} \mathrm{C}$ for $15 \mathrm{~min}$.

\section{Physic-Chemical Analysis of Soil Samples}

The $\mathrm{pH}$ was determined electrometrically by suspending the soil in 1: 2 (soil: $0.01 \mathrm{M} \mathrm{CaCl}_{2}$ ) mixture. The suspension of the soil was allowed to stand for 30 minutes with occasional stirring and the $\mathrm{pH}$ measured with a $\mathrm{pH}$ meter [6]. Moisture an aluminium dish was pre weighed $\left(\mathrm{W}_{1}\right)$ using a sensitive weigh balance (State Model). Ten (10) grams of the fresh soil sample was transferred to the dish and weight of both the dish and soil was noted $\left(\mathrm{W}_{2}\right)$. The dish containing the soil sample was placed in a hot air oven (State Model) at $130^{\circ} \mathrm{C}$ and dried to obtain a constant weight for 24 hours. The dish was immediately transferred to a desiccator and allowed to cool for 30 minutes. The resultant weight was taken $\left(\mathrm{W}_{3}\right)$. The moisture content was calculated and recorded as a percentage by weight of the respective soil sample.

\section{Total Organic carbon}

The Total Organic Carbon was determined by the Walkley-Black titrimetric method. About $0.3 \mathrm{~g}$ of each soil samples were weighed into an Erlenmyer flask with $10 \mathrm{ml}$ of $\mathrm{K}_{2} \mathrm{CrO}_{7}$ and $20 \mathrm{ml}$ concentration $\mathrm{H}_{2} \mathrm{SO}_{4}$ was added. The mixture was gently swirled until soil and reagents were properly mixed and were allow to stand for $30 \mathrm{~min}, 100$ $\mathrm{ml}$ of distilled water was added and the content titrated against standardized ferrous sulphate solution to a reddish brown end point using ferroin as the indicator. The total organic matter was calculated from the value obtained for the total organic carbon [7].

\section{Total hydrocarbon content}

Hydrocarbon-utilizing bacteria population was enumerated by spread plate technique [7]by inoculating $0.1 \mathrm{ml}$ of aliquot onto sterile Mineral Salt Medium (MSM) plates with $100 \mu \mathrm{l}$ each of petroleum products viz; diesel (AGO), petrol (PMS), pure kerosene (DPK) and mixed kerosene (DPK). The petroleum products used was sterilized by filtering through Millipore filter, $0.45 \mu$ diameter and stored in sterile bottles. The petroleum products were used as the sole carbon source to isolate hydrocarbon-utilizing bacteria. Theplates were incubated at $25^{\circ} \mathrm{C}$ for 3-5 days. Any isolate which grow on nutrient agar plates but failed to grow on mineral salt medium plate were confirmed as non-degraders. The isolates which grow on both the agar plates were confirmed as hydrocarbon utilizes. Total hydrocarbon content was calculated as described by[8] (Figure 1). 


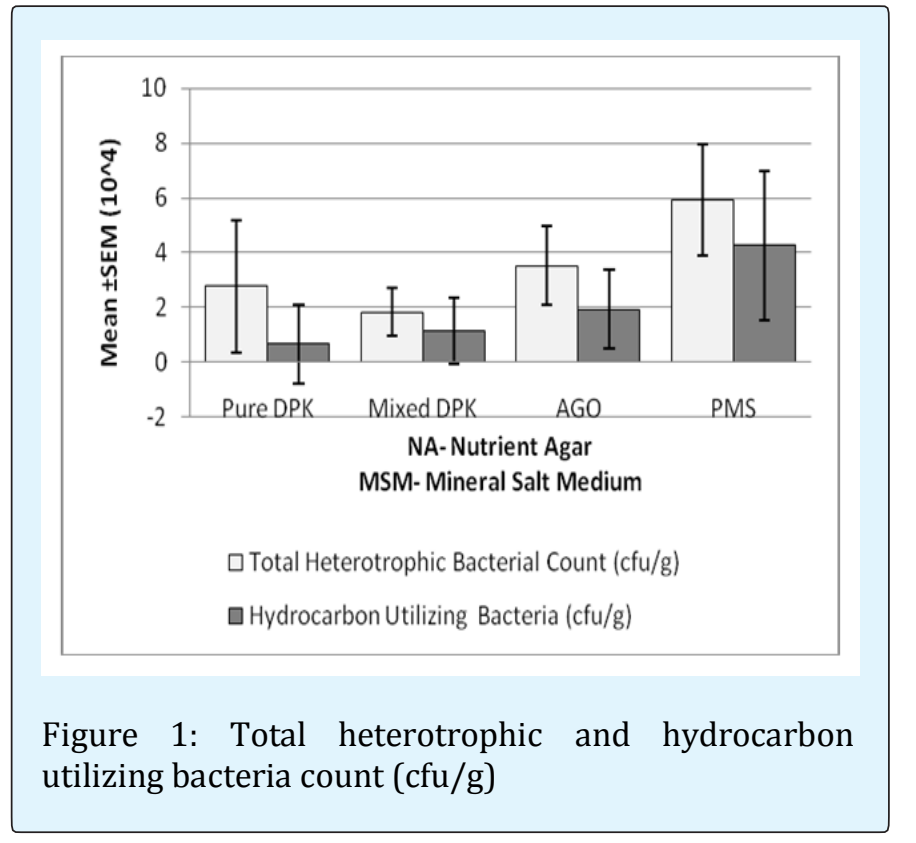

\section{Available phosphorus}

One gramme $(1.0 \mathrm{~g})$ of soil was shaken for 5 minutes with $10 \mathrm{ml}$ of extracting solution containing $0.03 \mathrm{~N} \mathrm{NH} 4 \mathrm{~F}$ and $0.1 \mathrm{~N} \mathrm{HCl}$ ). The solution was filtered through Whatman filter paper and $3 \mathrm{ml}$ of the filtrate was transferred into a test tube and $3 \mathrm{ml}$ of ammonium molybdate was added. Thereafter, 5 drops of mixture of boric acid, sodium sulphite and sodium sulphates were added. The Phosphorus content was determined calorimetrically [9].

\section{Available nitrogen}

One gramme $(1.0 \mathrm{~g})$ of the soil sample was placed into Kjedahl digestion flask. One table of a catalyst and $20 \mathrm{ml}$ concentrated tetraoxosulphate acid was added and the mixture was hand shaken to ensure mixing. At completion of digestion, $10 \mathrm{ml}$ distilled water was added and the solution was filtered through a Whatman filter paper. Nitrogen was determined calorimetrically at $625 \mathrm{~nm}$ [9].

\section{Total heterotrophic bacteria}

THB population was enumerated by pour plate method. $1 \mathrm{~g}$ of the sample was aseptically transferred into $100 \mathrm{ml}$ of physiological saline and transferred in a series of eight 10 fold serial dilution using physiological saline. $1 \mathrm{ml}$ of the aliquot from each of the dilution of $10^{2}, 10^{4}, 10^{6}$ and $10^{8}$ was inoculated by pour plate method onto Nutrient agar (NA) in duplicates. The plates were incubated aerobically at room temperature for $48-72$ hrs. The resulting colonies were counted and recorded as colony forming units per gram (cfu/g) of soil sample [10].

\section{Characterization and Identification of Isolates}

The enumerated bacteria were isolated and stored in NA slants at $4^{\circ} \mathrm{C}$ for further identification. Primary identification was done on the basis of colony and cell morphology and Gram staining. Colonial examination of the isolates was carried out to determine the type of shape, elevation and pigmentation pattern they exhibited [11]. Secondary identification is carried out by performing a series of Biochemical tests,[12] (Table 1).

\begin{tabular}{|c|c|c|c|c|c|c|c|c|c|}
\hline Characteristics & 1 & 2 & 3 & 4 & 5 & 6 & 7 & 8 & 9 \\
\hline \multicolumn{10}{|c|}{ Cultural Morphology } \\
\hline Elevation & Flat & Convex & $\begin{array}{c}\text { Low } \\
\text { convex }\end{array}$ & Convex & Convex & $\begin{array}{l}\text { Low } \\
\text { Convex }\end{array}$ & $\begin{array}{l}\text { Low } \\
\text { Convex }\end{array}$ & $\begin{array}{l}\text { Low } \\
\text { Convex }\end{array}$ & $\begin{array}{l}\text { Low } \\
\text { Convex }\end{array}$ \\
\hline Margin & Serrated & Entire & Entire & Smooth & Entire & Entire & Entire & Entire & Entire \\
\hline Colour & Cream & Orange & Green & Cream & Cream & Cream & Cream & Cream & Cream \\
\hline Shape & Irregular & Circular & Circular & Circular & Circular & Circular & Circular & Circular & Circular \\
\hline \multicolumn{10}{|c|}{ Morphological } \\
\hline Gram stain & + & + & - & - & - & + & + & + & - \\
\hline Spore staining & + & - & - & - & - & - & - & - & - \\
\hline Cell type & Rod & Cocci & Rod & Rod & Rod & Rod & Rod & Rod & Rod \\
\hline $\begin{array}{c}\text { Cell } \\
\text { Arrangement } \\
\end{array}$ & Chains & Single & Single & Single & Single & Single & Chain & Single & Single \\
\hline \multicolumn{10}{|c|}{ Biochemical } \\
\hline Catalase & + & + & + & + & + & + & + & + & + \\
\hline Oxidase & ND & ND & + & - & + & - & - & ND & + \\
\hline Coagulase & ND & - & ND & ND & ND & ND & - & ND & ND \\
\hline
\end{tabular}




\section{Open Access Journal of Microbiology \& Biotechnology}

\begin{tabular}{|c|c|c|c|c|c|c|c|c|c|}
\hline Urease & + & + & - & + & - & + & - & + & - \\
\hline Indole & ND & - & - & - & - & - & - & - & - \\
\hline Citrate & + & + & + & + & + & + & + & + & + \\
\hline Glucose & + & + & + & + & + & + & + & - & + \\
\hline Lactose & - & - & - & - & - & - & - & - & - \\
\hline
\end{tabular}

Table 1: Cultural, Morphological and Biochemical Characteristics of Bacteria Isolates

Likely Identifiable organisms

$* 1=$ Bacillussubtilis $\quad * 2=$ Micrococcusvarians $* 3=$ Pseudomonasaeruginosa $\quad * 4=\quad$ Klebsiellaaerogenes $* 5=$ Alcaligenes sp. ${ }^{*} 6=$ Corynebacterium sp. $\quad{ }^{*} 7=$ Bacillus sp. ${ }^{*} 8=$ Arthrobacter sp. ${ }^{*} 9=$ Pseudomonas $\mathrm{sp}$.

\section{Results and Discussion}

The physicochemical parameters are show in Table 2. The $\mathrm{pH}$ of pure dual purpose kerosene (DPK) is slightly higher (6.7) than that of premium motor spirit(PMS), automobile oil and gas (AGO), and mixed dual purpose kerosene (DPK) which are 6.60, 6.50, and 6.60 respectively. The conductivity of pure DPK is higher (32.50mhos $/ \mathrm{cm}$ ) compared to the PMS, AGO and Mixed DPK. The moisture content of pure DPK was more with $14.50 \%$ while that of PMA AGO, and Mixed DPK were $10.20 \%, 10.80 \%$ and $10.20 \%$ respectively. Total Carbon content was higher in AGO (4.75\%) compared to PMS, Mixed DPK and Pure DPK which have 2.19\%, 1.38\% and $2.97 \%$ respectively. Total organic matter, Nitrogen and Phosphate $(8.19 \%, 0.95 \%$ and $5.52 \%$ respectively) were also higher in AGO. The total heterotrophic bacteria were higher in nutrient agar plates than in MSM which was spread with $0.1 \mathrm{ml}$ of petroleum products. The total heterotrophic bacteria count is shown in Table 3. The population density of heterotrophic bacteria in soil sample contaminated with PMS was $5.93 \times 10^{4} \pm 0.20$ which was highest compared to the soil contaminated with AGO, pure DPK and mixed DPK with population densities of $3.53 \times 10^{4} \pm 0.15, \quad 2.77 \times 10^{4} \pm 0.24$ and $1.83 \times 10^{4} \pm 0.09$ respectively.

\begin{tabular}{|c|c|c|c|c|}
\hline Parameters & PMS & AGO & $\begin{array}{c}\text { Mixed } \\
\text { DPK }\end{array}$ & $\begin{array}{c}\text { Pure } \\
\text { DPK }\end{array}$ \\
\hline pH & 6.6 & 6.5 & 6.6 & 6.7 \\
\hline $\begin{array}{c}\text { Conductivity } \\
\text { (mhos/cm) }\end{array}$ & 14.6 & 14.2 & 15.1 & 32.5 \\
\hline Moisture (\%) & 10.2 & 10.8 & 10.2 & 14.5 \\
\hline Carbon (\%) & 2.19 & 4.75 & 1.38 & 2.97 \\
\hline $\begin{array}{c}\text { Organic matter } \\
\text { (\%) }\end{array}$ & 3.78 & 8.19 & 2.37 & 5.12 \\
\hline Nitrogen (\%) & 0.652 & 0.95 & 0.396 & 0.717 \\
\hline Phosphate (\%) & 3.71 & 5.52 & 1.95 & 4.03 \\
\hline THC (mg/kg) & 1,860 & 3,050 & 125 & 1,040 \\
\hline
\end{tabular}

Table 2: Physicochemical parameters of the soil samples contaminated with petroleum products

\section{Key}

AGO - Automotive Gas \& Oils

DPK - Dual Purpose Kerosene.

PMS - Premium Motor Spirit.Another name for gasoline.

\begin{tabular}{|c|c|}
\hline Samples & Viable cell Count $(\mathbf{c f u} / \mathbf{m l})$ \\
\hline Pure DPK & $2.77 \times 10^{4} \pm 0.24$ \\
\hline Mixed DPK & $1.83 \times 10^{4} \pm 0.09$ \\
\hline AGO & $3.53 \times 10^{4} \pm 0.15$ \\
\hline PMS & $5.93 \times 10^{4} \pm 0.20$ \\
\hline
\end{tabular}

Table 3: Total Heterotrophic Bacterial Count (cfu/ml) Where DPK-dual purpose kerosene, AGO-automobile oil and gas and PMS- premium motor spirit

The number of colonies on mineral salt medium is lower when compared to the mother plate without hydrocarbons. These results showed that the bacteria grown on enriched medium were able to utilize the hydrocarbon. The morphological and biochemical characterization of the bacterial isolates obtained from the different soil collected from different spot from the Tank farm revealed the following isolates; Bacillussubtilis, Micrococcusvarians, Pseudomonasaeruginosa, Klebsiellaaerogenes, Alcaligenes sp., Corynebacterium sp., Bacillussp., Arthrobactersp. and Pseudomonas sp. Bacillus subtilis, Pseudomonas aeroginosa, Bacillus sp., Pseudomonas sp. were present in all soil samples. Alcaligenes sp. was isolated from pure DPK, Micrococcussp. was present in PMS and Mixed DPK, Klebsiellaaerogenespresent in Mixed DPK, Alcaligenessp. was present in AGO, Corynebacterium sp. Present in pure DPK, Arthrobacter sp. was present in pure DPK, while Pseudomonassp. was present in PMS. All the isolates are rod shaped except Micrococcus varians which is cocci in shape. Their cells are arranged singly except for the Bacillus sp. which occurs in chains. The biochemical test reveals all to be catalase positive, all negative for indole, citrate and lactose test, and all positive for glucose test with the exception of Arthrobactersp. Interestingly these organisms have been implicated in hydrocarbon degradation. Many scientists studied the petroleum 


\section{Open Access Journal of Microbiology \& Biotechnology}

degradation by various Pseudomonas species, Bacillus species, Micrococcussp and Alcaligenes [13-16]. Jyothi et al. [17] also isolated Bacillus species, Micrococcus luteus, Corynebacteriumxerosisfrom petroleum contaminated soil. The physico-chemical properties and microbial loads of soil showed that there are essential nutrients in soil especially nitrate and phosphate necessary for microbial growth. The microorganisms isolated were: Bacillussubtilis, Micrococcusvarians, Pseudomonasaeruginosa, Klebsiellaaerogenes, Alcaligenes sp., Corynebacterium sp., Bacillussp., Arthrobactersp., and Pseudomonassp. The presence of microorganisms in the hydrocarbon contaminated soil samples showed that soil indigenous microflora can metabolize crude oil or hydrocarbons in contaminated sites.

\section{Conclusion}

The presence of microorganisms in the hydrocarbon contaminated soil samples showed that soil indigenous microflora can metabolize crude oil or hydrocarbons in contaminated sites and these bacteria under the stated soil condition can enhance bioremediation of petroleum contaminated soil. This study reveals the possible biodegradability of several petroleum products by bacteria which will aid the bioremediation of the contaminated soil. Further research in genetically modified bacteria that will be able to degrade all types of petroleum products which will advance the bioremediation of contaminated soil.

\section{References}

1. Aniefiok IE,Udo JI, Margaret UI,Sunday WP (2013) Petroleum Exploration and Production: Past and Present Environmental Issues in the Nigeria's Niger Delta.American Journal of Environmental Protection 1(4): 78-90.

2. Santos HF, Carmo FL, Paes JE, Rosado AS,Peixoto RS (2011)Bioremediation of mangroves impacted by petroleum.Water Air and Soil Pollution216(1): 329350.

3. Korda a, Santas P, Tenente A,Santas R(1997) Petroleum hydrobcarbon bioremediation: sampling and analytical techniques, in situ treatments and commercial microorganisms currently used. Applied Microbiology and Biotechnology 48(6): 677-686.

4. Margesin R, Schinner F(1997) Bioremediation of diesel-oil contaminated alpine soils at low temperatures. Applied Microbiological Biotechnology 47(4):462-468.

5. Alexander M (1994) Biodegradation and Bioremediation, Academic Press, San Diego,Califonia, USA, p: 56.

6. Kalra YP, Maynard DG (1991) Methods Manual for Forest soil and Plant Analysis. Edmonton, Canadian Forest Service Publications, Canada, pp: 116.

7. Udochukwu U, OmoghieEM, Chikezie CC,UdinyiweOC(2014) The Role of Bacteria in the Mineralization of Diesel-Base Engine Oil. International Journal of Pharmaceutical Science Invention3 (7): 50-55.

8. Emitiazi G, Etemadifar Z, Tavassoli M (2003)A novel nitrogen-fixing cellulitic bacterium associated with root of cam is a candidate for production of single cell protein. Biomass Bioenergy25 (4):423-426.

9. Onyeonwu RO (2000) Manual for Waste/Wastewater, Soil/ Sediment, Plant and Fish analysis. MacGill Environmental Research Laboratory Manual, Benin City, pp: 81.

10. Chikere CB, Okpokwasili GC,Ichiakor O (2009) Characterization of hydrocarbon utilizing bacteria in tropical marine sediments.African Journal of Biotechnology 8(11): 2541-2544.

11. Udochukwu U, Inetianbor J, Omorotionmwan FO, Okpuruka NS (2016) Effects of High Customer Patronage on the Indoor Air Quality of Restaurants in Lokoja Metropolis and Its Public Health Impact. American Journal of Microbiological Research 4(2): 51-55.

12. Cheesbrough M (2010) Microscopical Techniques Used in Microbiology In: District Laboratory Practice in Tropical Countries Part2. Cambridge Low-Price Edition, Cambridge University Press. pp. 35-70.

13. Amund O0, Adebiyi AG (1991) Effect of viscosity on the biodegradability of automotive lubricating oils. Tribol Intern 24: 235-237.

14. Nwachukwu SCU (2001) Bioremediation of sterile agricultural soils polluted with crude petroleum by application of the soil bacterium, Pseudomonas putida, with inorganic nutrient supplementations. CurrMicrobiol 42(4): 231-236. 
15. Adriano PM, de Arruda, APGK, Dejanira FA,Bonotto DM (2007)Laboratory Study on the Bioremediation of Diesel Oil contaminated soil from a petrolstation. Brazilian Journal of Microbiology 38:346-353.

16. Yousefi KD, Khodadadi A,Ganjidoust H, Badkoubi A,Amoozegar MA (2009) Isolation and characterization of a novel native Bacillus strain capable of degrading diesel fuel. Int J EnvironSci Tech 6(3):435-442.

17. Jyothi K, Babu KS, Nancy CK, Kashyap A (2012) Identification and Isolation of Hydrocarbon Degrading Bacteria by Molecular Characterization. Helix (2): 105-111.

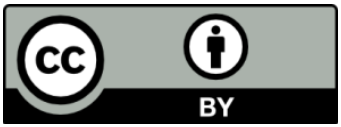

